\title{
Redescription of Remaneicaris ignotus (Dussart, 1983), a Parastenocarididae (Copepoda, Harpacticoida) with an unusual set of plesiomorphic characters
}

\author{
Paulo Henrique Costa Corgosinho1, Pedro Martínez Arbizu², \\ Edinaldo Nelson dos Santos-Silva ${ }^{3}$
}

\author{
${ }^{I}$ Plankton Laboratory, CPBA/ INPA, Av. André Araújo, 2936 Petrópolis, CP 478, 69011-970, \\ Manaus-AM, Brazil. e-mail: pcorgo@yahoo.com.br \\ ${ }^{2}$ DZMB - Forschungsinstitut Senckenberg, Südstrand 44, 26382 Wilhelmshaven, Germany. \\ e-mail: pmartinez@senckenberg.de \\ ${ }^{3}$ Plankton Laboratory, CPBA/ INPA, Av. André Araújo, 2936 Petrópolis, CP 478, 69011-970, \\ Manaus-AM, Brazil. e-mail: nelson@inpa.gov.br
}

ABSTRACT: In the course of a phylogenetical analysis of the family Parastenocarididae we re-describe here both sexes of Remaneicaris ignotus (Dussart, 1983) and its phylogenetic position within the genusRemaneicaris is briefly discussed. This species can be distinguished from the other species of the genus by the following autapomorphies: absence of an outer seta on the basis of the leg 1 in both sexes; presence of a very sclerotized body of uneven cuticle; presence of a less sclerotized plate between the fifth legs that is not homologous to an intercoxal plate, and presence of an irregularly-shaped endopod of leg 4 in males, which is hirsute on the proximal outer margin and with a distal hyaline seta. This species also can be easily identified by the presence of several unusual plesiomorphic characters, unknown so far from any other member of the genus, such as a dorsal integumental window on all urosomites, an inner seta on the basis of leg 1 in males and females, the ventral position of leg 5 and the linear distribution of the proximal outer row of spinules on exopodite 1 of legs 2 and 4 .

KEY WORDS: Remaneicaris ignotus, Parastenocarididae, South America, groundwater, plesiomorphies.

\section{Переописание Remaneicaris ignotus (Dussart, 1983), представителя Parastenocarididae (Copepoda, Harpacticoida) с необычным набором примитивных признаков}

\section{П.Х.К. Коргосинхо', П. Мартинез Арбизуㄹ, Е. Нелсон Дос Сантос-Сильва ${ }^{3}$}

\footnotetext{
${ }^{I}$ Plankton Laboratory, CPBA/ INPA, Av. André Araújo, 2936 Petrópolis, CP 478, 69011-970, Manaus-AM, Brazil. e-mail: pcorgo@yahoo.com.br

${ }^{2}$ DZMB - Forschungsinstitut Senckenberg, Südstrand 44, 26382 Wilhelmshaven, Germany. e-mail: pmartinez@senckenberg.de

${ }_{3}^{3}$ Plankton Laboratory, CPBA/ INPA, Av. André Araújo, 2936 Petrópolis, CP 478, 69011-970, Manaus-AM, Brazil. e-mail: nelson@inpa.gov.br
} 
PЕЗЮМЕ: В данной работе в рамках исследования филогенетических отношений семейства Parastenocarididae переописаны самец и самка вида Remaneicaris ignotus (Dussart, 1983) и вкратце обсуждается филогенетическое положение вида в роде Remaneicaris. Вид отличается от других представителей рода следующими уникальными признаками: наружная щетинка базиса первой ноги отсутствует как у самцов, так и самок; кутикула склеротизирована; пластинка, располагающаяся между пятыми ногами и не гомологичная интеркоксальной, склеротизирована незначительно; эндоподит 4-й плавательной ноги самца неправильной формы, его наружный край проксимально несет многочисленные щетиночки и вооружен дистальной гиалиновой щетинкой. Вид также хорошо отличается наличием примитивных признаков, до настоящего времени не отмеченным у других представителей рода: интегументные окна (integumental windows) присутствуют на дорзальной стороне всех сегментов уросомы, базис 1-ой плавательной ноги самца и самки несет внутреннюю щетинку, 5-я нога имеет вентральное положение, проксимальный наружный ряд шипиков первого сегмента экзоподита 2-й и 4-й плавательных ног имеет линейное расположение.

КЛЮЧЕВЫЕ СЛОВА: Remaneicaris ignotus, Parastenocarididae, Южная Америка, грунтовые воды, плезиоморфные признаки.

\section{Introduction}

The genus Remaneicaris Jakobi, 1972 is, until now, the most diverse taxon of Parastenocarididae in Latin America, including 31 described species. The geographical distribution of its composing species extends from Argentina (Patagonia) to El Salvador (Central America); R. psammae (Rouch, 1962) is the most meridional species, while $R$. meyerabichi (Noodt, 1962) and R. palaciosi (Noodt, 1962) show the most northern distribution.

Members of Remaneicaris share, as synapomorphies, the subdistal position of the outer spine on the exopodite 3 of leg 4 , the absence of an intercoxal sclerite on leg 5 and a medially located spinule on the third exopodite of leg 2 and 4. Additionally, most of them have also the presence of a lateral integumental window on each side of the last urosomite (Corgosinho \& Martínez Arbizu, 2005). They also share an unusual set of plesiomorphic characters within the family such as a nine-segmented antennule in males, first endite of maxilla with two setae, second endite with three slender setae and leg 3 of males with one-segmented endopod.

Groundwater copepods from Argentina were primarily studied by Noodt (1965) and later by
Dussart (1983). This fauna resulted to be very diverse, being represented by species from different evolutionary lineages within Remaneicaris. Most of the species described by Noodt, with the exception of $R$. argentina (Noodt, 1965 ) and R. jujuyensis (Noodt, 1965) belong to a more derived group within this genus. However, in samples taken from Laguna Sirena (province of Corrientes), Dussart (1983) found a very peculiar parastenocaridid and described it as Parastenocaris ignotus Dussart, 1983; later it was transferred to the genus Remaneicaris by Corgosinho \& Martínez Arbizu (2005). Within this genus, $R$. ignotus shows a special set of plesiomorphic characters not known so far from any other member and which indicate its basal position within the genus.

In this work we redescribe both genders of $R$. ignotus and the presence of some unusual plesiomorphic characters within the genus is discussed.

\section{Material and methods}

Type species of R. ignotus was loaned from the collection of the Muséum national d'Histoire naturelle (Paris). Due to the bad state of the type species, the redescription was based on the 
observation of paratypes dissected by the authors. Animals were dissected in lactic acid and mounted on slides in glycerine. Drawings were made with a Leica DMR microscope, with Normarsky interference contrast and using a drawing tube, at 400x and 1000x magnification.

Abbreviations: A1 - antennule, A2 - antenna, Ae - aesthetasc, Md - mandible, Mx1 Maxillule, Mx2 - Maxilla, Mxp - maxilliped, endopod - enp, exopod - exp, autR - autapomorphy for Remaneicaris, aut - autapomorphy.

\section{Order Harpacticoida Sars, 1903}

Parastenocarididae Chappuis, 1940

Remaneicaris Jakobi, 1972

Remaneicaris ignotus (Dussart, 1983)

Parastenocaris ignotus. Dussart, 1983: 16, Figs 1-8; Corrales de Jacobo \& Frutos, 1985: 43-48.

Remaneicaris ignotus. Corgosinho \& Martínez Arbizu 2005: 147-162.

MATERIAL. Holotype - 1 partially dissected male, mounted in 2 slides and deposited at Muséum national d'Histoire naturelle (MNHM; Paris, France), labelled MNHM-CP666. Paratypes: 1 male dissected and mounted on 7 slides, labelled MNHM-CP2204; 1 female dissected and mounted on 7 slides, labelled MNHM-CP2205; 1 undissected female mounted on 1 slide MNHM-CP2206; 1 undissected female mounted on 1 slide MNHM-CP2207 and 7 females from the same locality as the holotype, preserved in alcohol and deposited at MNHN (Paris, France), under the number MNHM-CP928.

DISTRIBUTION. Laguna Sirena, among the cities of Itá Ibaté and Ituzaingó (Corrientes province, Argentina).

DIAGNOSIS. Parastenocarididae with 9-segmented antennule on males and 7-segmented on females. Dorsal integumental windows on cephalothorax, $2^{\text {nd }}-5^{\text {th }}$ urosomite of males and $2^{\text {nd }}-4^{\text {th }}$ of females. Body heavily sclerotized and with uneven cuticle over all of the surfaces. Telson not ornamented. Mx 2 with 2 setae on the $1^{\text {st }}$ endite and 3 slender setae on the $2^{\text {nd }}$. Leg 1 without sexual dimorphism and with a seta on the inner margin of basis. Exp 1 of legs 2 and 4 with a linear row of spinules, proximally, on the outer margin. Third exp of legs 2 and 4 with a spinule medially placed on the outer margin. Leg 3 of male with 1-segmented enp; exp slightly curved, without ornamentation on the outer margin; apophysis is short and rounded; thumb is strong and sshaped. Leg 4 with a subdistal seta on outer margin of exp 3; enp of males irregular and hirsute on proximal region and with distal hyaline seta. Leg 5 small, quadratic, ventrally positioned, with all setae distally located and without intercoxal sclerite.

DESCRIPTION. Male. Habitus (Fig. 1A,B). Length $410 \mu \mathrm{m}$ (measured from tip of rostrum to distal rim of anal operculum). Body heavily sclerotized and with uneven cuticle over all of the surfaces. Rostrum not fused to cephalothorax, with wide base and 2 sensilla on the tip. Cephalothorax and urosomites with 1 dorsal integumental window each. Dorsal pores on cephalothorax, thoracic somites 1 and 3 and second urosomite; 1 pair of lateral pores on telson. For sensilla on tergites see fig. 1A \& B. Telson longer than wide (Figs 1A,B; 2A,B), approximately as long as the 2 previous somites together. Anal operculum smooth and slightly concave (Figs 1B \& 2B). Furca (Figs 1A,B \& 2A,B) about 4 times as long as wide, with 7 setae, all located on distal third. A1 (Fig. 3A) 9-segmented and prehensile; armature beginning with proximal segment: $0 / 5 / 4 / 1$ / $5+\mathrm{Ae} / 1 / 3 / 1$ ? $/ 9+\mathrm{Ae} ; 1$ hyaline spine on the $7^{\text {th }}$ and $8^{\text {th }}$ segments. A2 (Fig. 3D) with allobasis; exp 1-segmented with 1 seta, and 1-segmented enp bearing an anterior hyaline frill and 7 setae. Bucal parts armature as follows (Fig. 3E): Md with coxal gnathobasis bearing 1 seta and a palp with 2 setae; Mx1 with precoxal arthrite with 5 elements ( 1 dorsal surface seta, 3 claw-like pinnate spines and 1 slender seta), coxa with 1 seta and basis with 3 setae; Mx 2 with 2 setae on proximal endite and 3 slender setae on distal endite, enp with 2 setae, 1 broken on right limb; Mxp 3 -segmented, distal segment with 1 claw-like seta. Leg 1 (Fig. 4A) coxa unarmed, with 2 rows of spinules on posterior side; basis without outer seta, with anterior pore, 3 spinules on outer margin, 4 distal spinules anterior to insertion of the enp and inner seta; enp 2-segmented, first segment without ornamentation on inner margin, with 2 rows of 2 spinules on outer margin and posterior hyaline frill; segment 2 with posterior hyaline frill and 2 distal setae, 1 geniculated; exp 3-segmented, segment 1 with outer spine, segment 2 unarmed, segment 3 with 2 outer spines and 2 geniculated setae. Coxa of leg 2 (Fig. 4B) unarmed, with 2 rows of spinules on posterior side; basis without outer seta, ornamented with 1 row of spinules on outer margin, 1 row of spinules near insertion of enp and 1 anterior pore near outer margin; exp 3-segmented; segment 1 with outer spine, hyaline frill on inner margin and with linear row of spinules, proximally, on outer margin (arrowed), segment 2 without armature, segment 3 broken (originally like female, with 3 setae, distal hyaline frill on inner corner and two spinules located medially on outer margin); enp 1-segmented with 1 subdistal seta and 3 distal spinules. Leg 3 (Fig. 4C) coxa unarmed and without ornamentation; basis with 1 outer seta and anterior row of larger spinules 


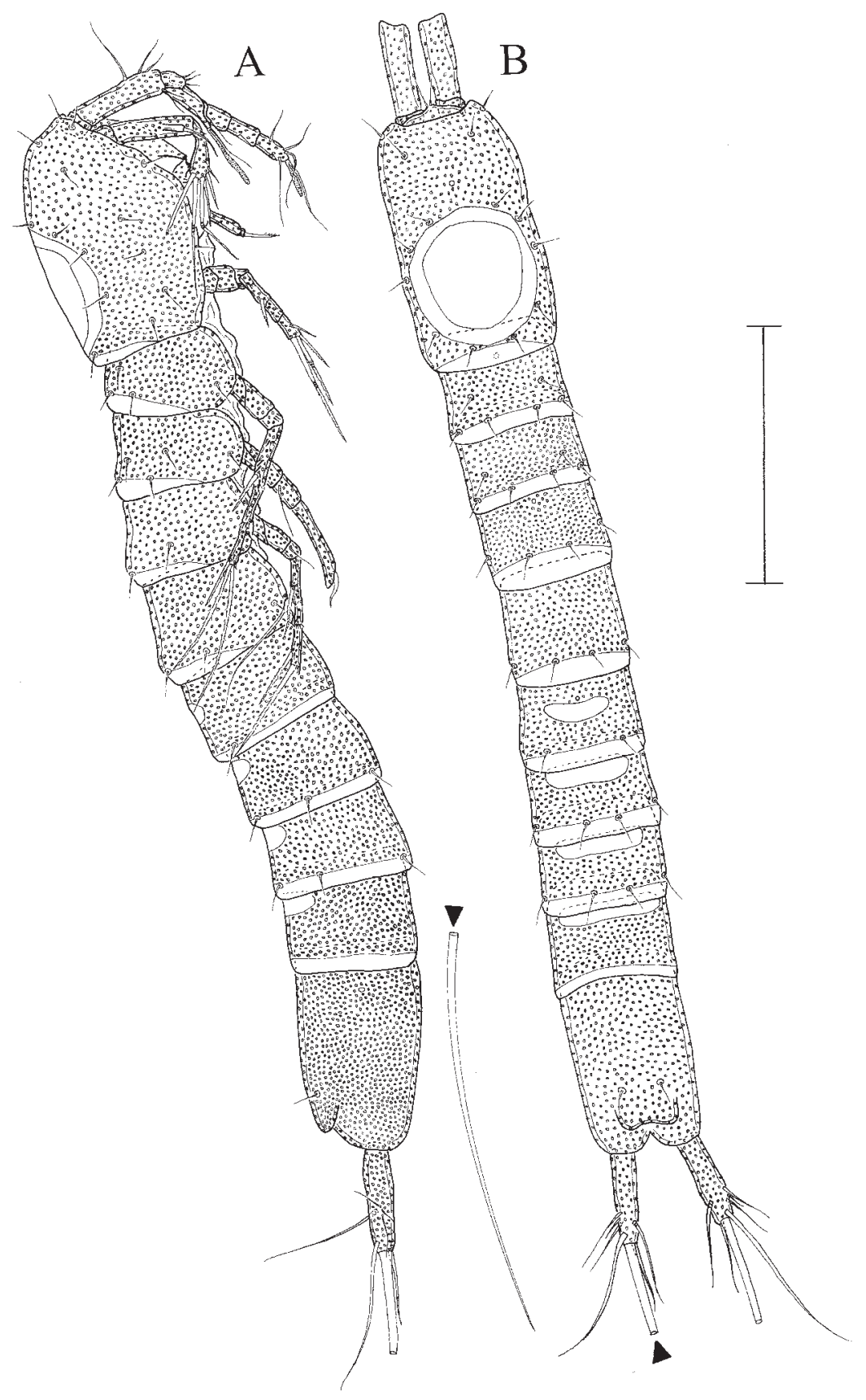

Fig. 1. Male lateral (A) and dorsal (B) habitus of Remaneicaris ignotus (Dussart, 1983). Scale bar $100 \mu \mathrm{m}$.

Рис. 1. Общий вид самца Remaneicaris ignotus (Dussart, 1983): вид сбоку (А) и вид со спины (В). Масштабный отрезок 100 мкм. 


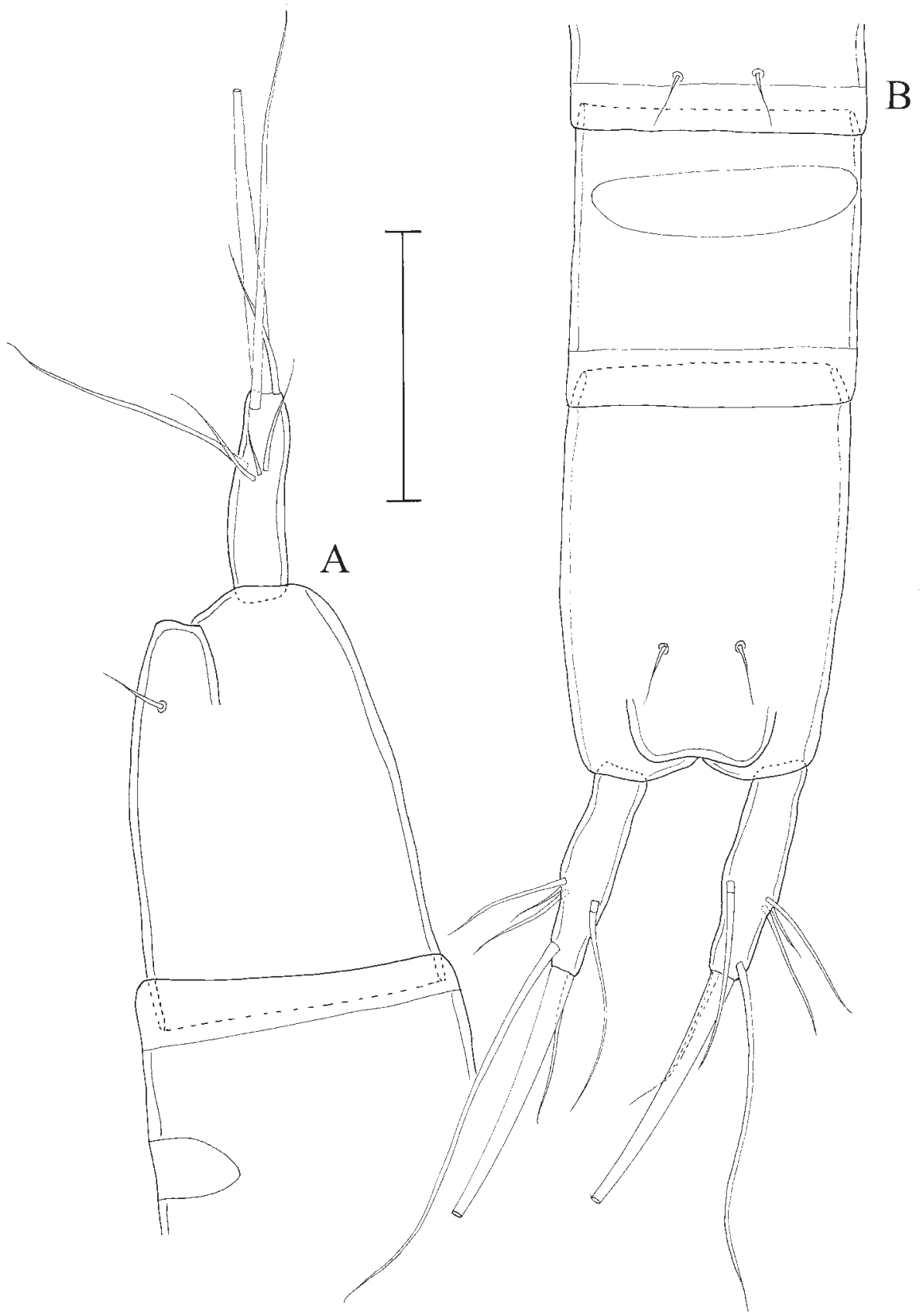

Fig. 2. Male last urosomite and telson of Remaneicaris ignotus (Dussart, 1983) in lateral (A) and dorsal view (B). Scale bar $50 \mu \mathrm{m}$.

Рис. 2. Последний сегмент уросомы и тельсон самца Remaneicaris ignotus (Dussart, 1983): вид сбоку (А) и вид со спины (B).

Масштабный отрезок 50 мкм. 


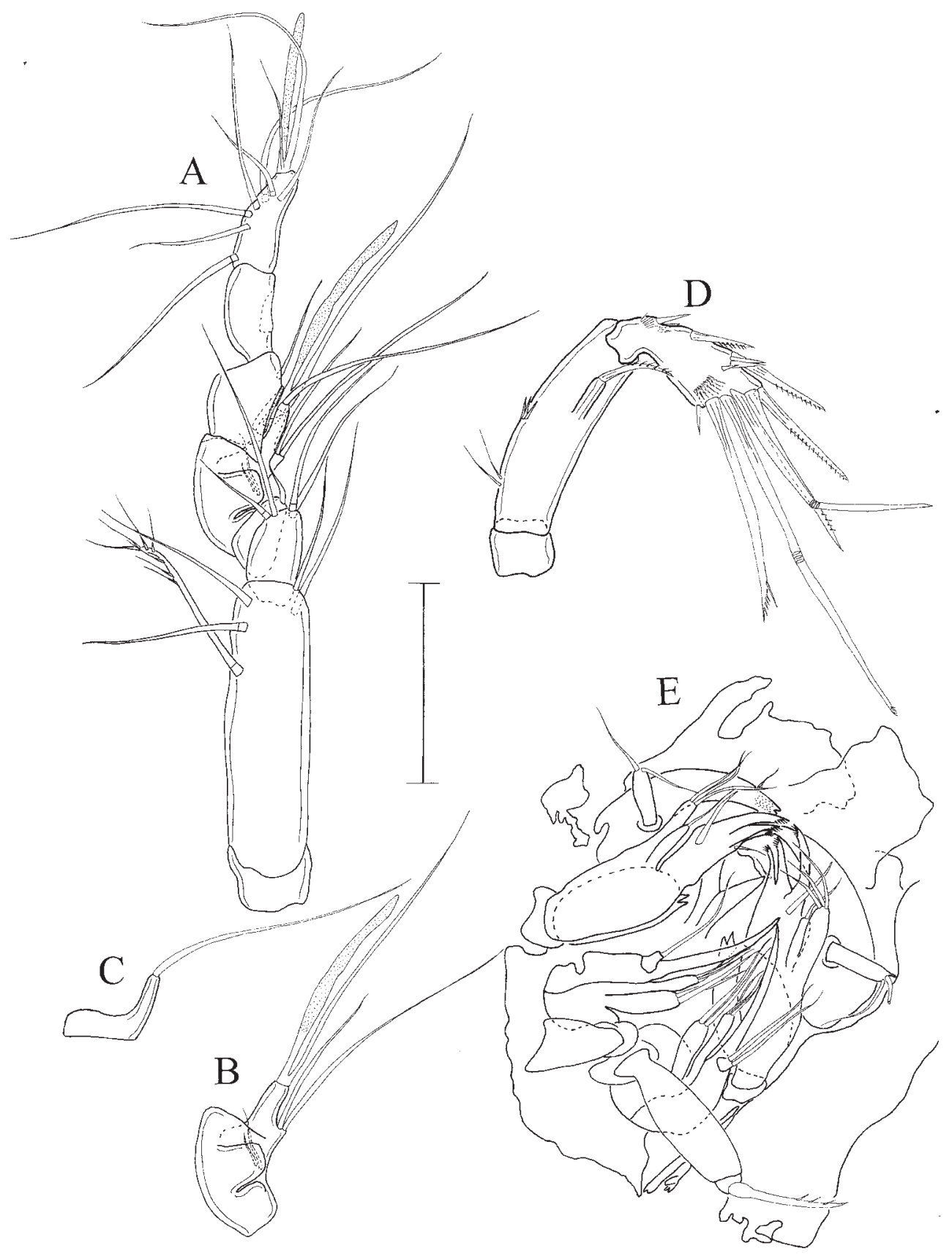

Fig. 3. Male antennule (A), 5th (B) and 6th (C) antennule segments, antenna (D) and bucal parts (E) of Remaneicaris ignotus (Dussart, 1983).

Scale bar $20 \mu \mathrm{m}$.

Рис. 3. Самец Remaneicaris ignotus (Dussart, 1983): антеннула (А), пятый членик антеннулы (В), шестой членик антеннулы (C), антенна (D), ротовые части (E).

Масштабный отрезок 20 мкм. 


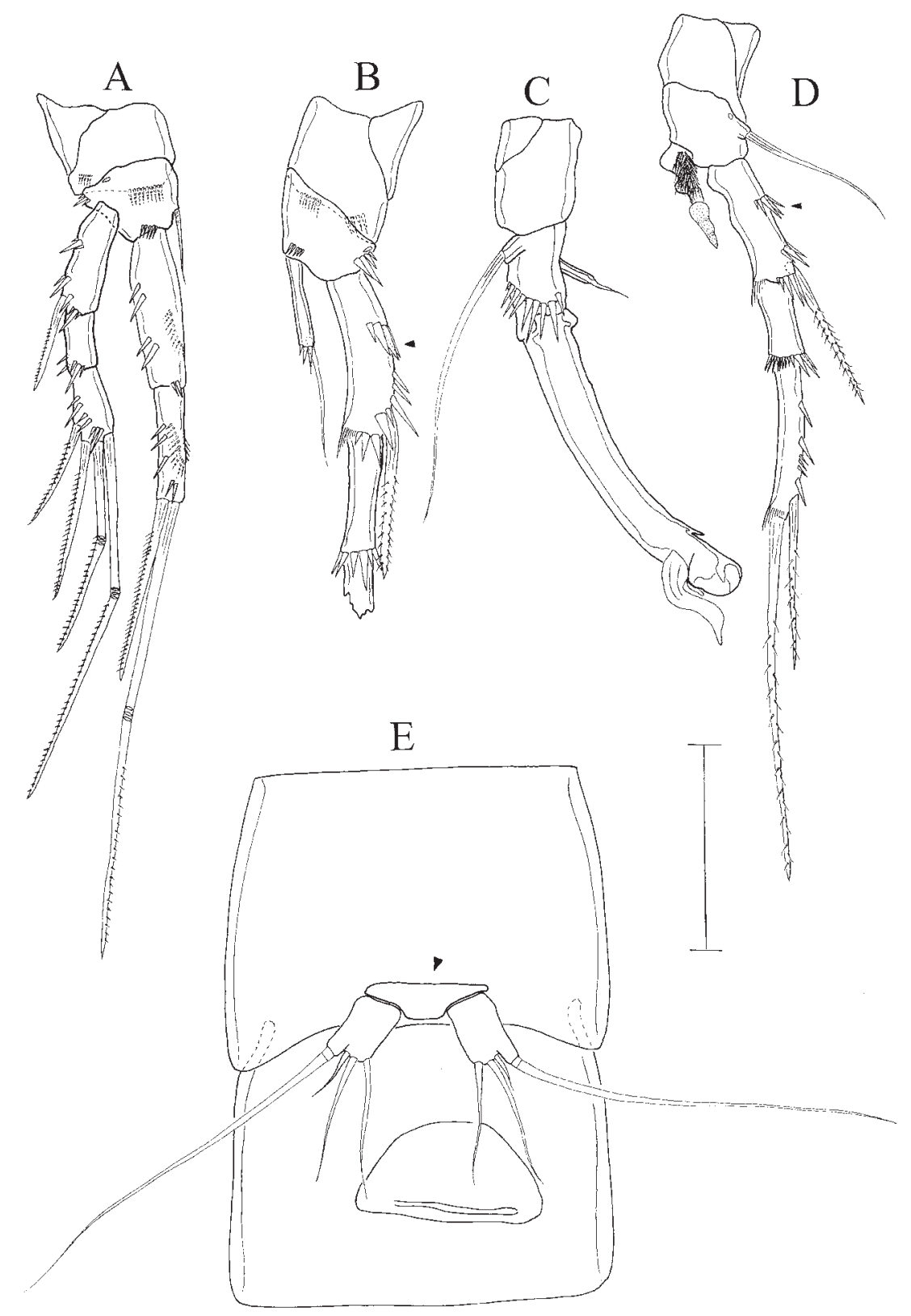

Fig. 4. Male leg 1 (A), leg 2 (B), leg 3 (C), leg 4 (D) and leg 5 (E) of Remaneicaris ignotus (Dussart, 1983). Scale bar $20 \mu \mathrm{m}$. Arrows indicate the linear row of spinules on the outer margin of first exopodal segment of legs 2 and 4 and a low chitinized zone without any articulation with the leg 5.

Рис. 4. Самец Remaneicaris ignotus (Dussart, 1983): плавательная нога 1 (А), плавательная нога 2 (В), плавательная нога 3 (C), плавательная нога 4 (D), нога 5 (Е).

Масштабный отрезок 20 мкм. Стрелки указывают на линейно располагающийся ряд шипиков на наружном крае первого членика экзоподита 2-й и 4-й плавательной ноги и слабо хитинизированную зону, лишенную подвижного сочленения с 5-й ногой. 
diagonally; enp unisegmented with 1 fused seta; exp 1-segmented, elongate, without spinules along outer margin, with 1 subdistal strong and curved seta (thumb); apophysis rounded. Leg 4 (Fig. 4D) coxa unarmed, basis with outer seta and 1 pore on anterior margin; exp 3-segmented, segment 1 with outer spine inserted distaly and with proximal row of spinules linearly arranged (arrowed) on outer margin, segment 2 without armature, segment 3 with 1 apical and 1 subdistal outer seta, distal hyaline frill on inner margin and 2 spinules located medially on outer margin; enp 1-segmented, irregular, hirsute, with 2 inner protuberances and distal hyaline seta. Leg 5 (Fig. 4E) quadrate and without inner spinulous process, ventrally located, and without intercoxal sclerite. Less cuticularized zone, not articulating with the leg 5, between contralateral limbs (Fig. 4E, arrowed).

Female. Habitus (Fig. 5A). Length $424 \mu \mathrm{m}$ (measured from the tip of rostrum to distal rim of the anal operculum). Rostrum as in male. Cephalothorax, double genital somite and subsequent urosomites with 1 dorsal integumental window each. Dorsal pores as in males and 1 pair of lateral pores on telson. For sensilla on tergites see fig. 5A. Telson, furca (Fig. 5A) and body sclerotized as in male. A1 (Fig. 6E) 7-segmented, not prehensile; number of setae beginning at proximal segment: $0 / 5 / 4 / 2+A e / 1 / 0$ ?, probably $1 / 9+$ Ae. A2 like in male, with allobasis; 1 segmented exp with 1 seta, 1 -segmented enp bearing 7 setae and posterior hyaline frill. Leg 1 and leg 2 (Fig. 6A,B) as in male. Leg 3 (Fig. 6C) coxa unarmed, with row of posterior spinules; basis with 1 outer seta, 1 anterior pore, 1 row of spinules near insertion of enp and 1 row between exp and outer seta; exp 2-segmented, segment 1 with outer spine, segment 2 with 1 spine and 1 seta; enp 1 -segmented and spiniform. Leg 4 (Fig. 6D) exp as in male; basis with row of small spinules near insertion of enp; enp spiniform with 1 incorporated distal seta. Leg 5 (Fig. 5B) quadrate, with small spiniform process on inner side. Genital field as illustrated in Fig. 5B, with single medially located copulatory pore. Gonopore transversal slit.

\section{Discussion}

Remaneicaris ignotus differs from the other species of the genus by the following synapomorphies: absence of an outer seta on the basis of the leg 1 in both sexes; presence of a heavily sclerotized body, with uneven cuticle over all of the surfaces; presence of a low sclerotized plate between the fifth legs, not homologous to the intercoxal sclerite and the presence of an irreg- ular leg 4 enp on males, hirsute on the proximal outer margin and with a distal hyaline seta.

The absence of an outer seta on the basis of leg 1 is a very interesting character, rarely appearing within the family. Within Remaneicaris, only R. ignotus has such character and the presence of this seta on the outgroup of Parastenocarididae (viz. Psammonitocrella Rouch, 1992; see Martínez Arbizu \& Moura, 1994), as well as in most of the described species of this family, suggests that absence of an outer seta on the basis of leg 1 is a character that appeared independently within the family, not composing, therefore, its groundpattern.

According to Dussart (1983), this species should be considered closely related to Parastenocaris sioli Noodt 1963 (hereafter Siolicaris sioli (Noodt, 1963); see ICZN, article 13) due to some "similarities" found in the furca. However, according to the same author, “....considering the endopodites, it would be better to group it with those species from the remanei-group..." (free translation). In our opinion, the morphology and ornamentation of the furca is not a phylogenetically informative character within the family, as already pointed out by Schminke (1991) who observed that the shape of the furca can be very variable, even between members of the same species, sometimes showing a very strong gender-linked dimorphism. In fact, in some descriptions of Noodt, such as the "aberrant" forms of Brasilibathynellocaris panamericana truncata (Noodt, 1962), Brasilibathynellocaris salvadorensis lanceolata (Noodt, 1962) as well as in some Remaneicaris species such as R. paraensis bulbifera (Noodt, 1963), R. paraguayensis phylloides (Noodt, 1963), R. ciliata (Noodt, 1965) and R. sanctiludovicci (Noodt, 1965), a gender-linked dimorphism occurs; female specimens with the normal or the transformed furca are often found in the same population. There are also few cases of transformed furca in males (Schminke 1991). In other species, outside the Neotropical Region, this phenomenon also occurs (viz. Schminke 1991). Besides, a closer observation of this structure reveals that in R. ignotus, as well as in all other Remaneicaris species, the dorsal seta (seta VII) 


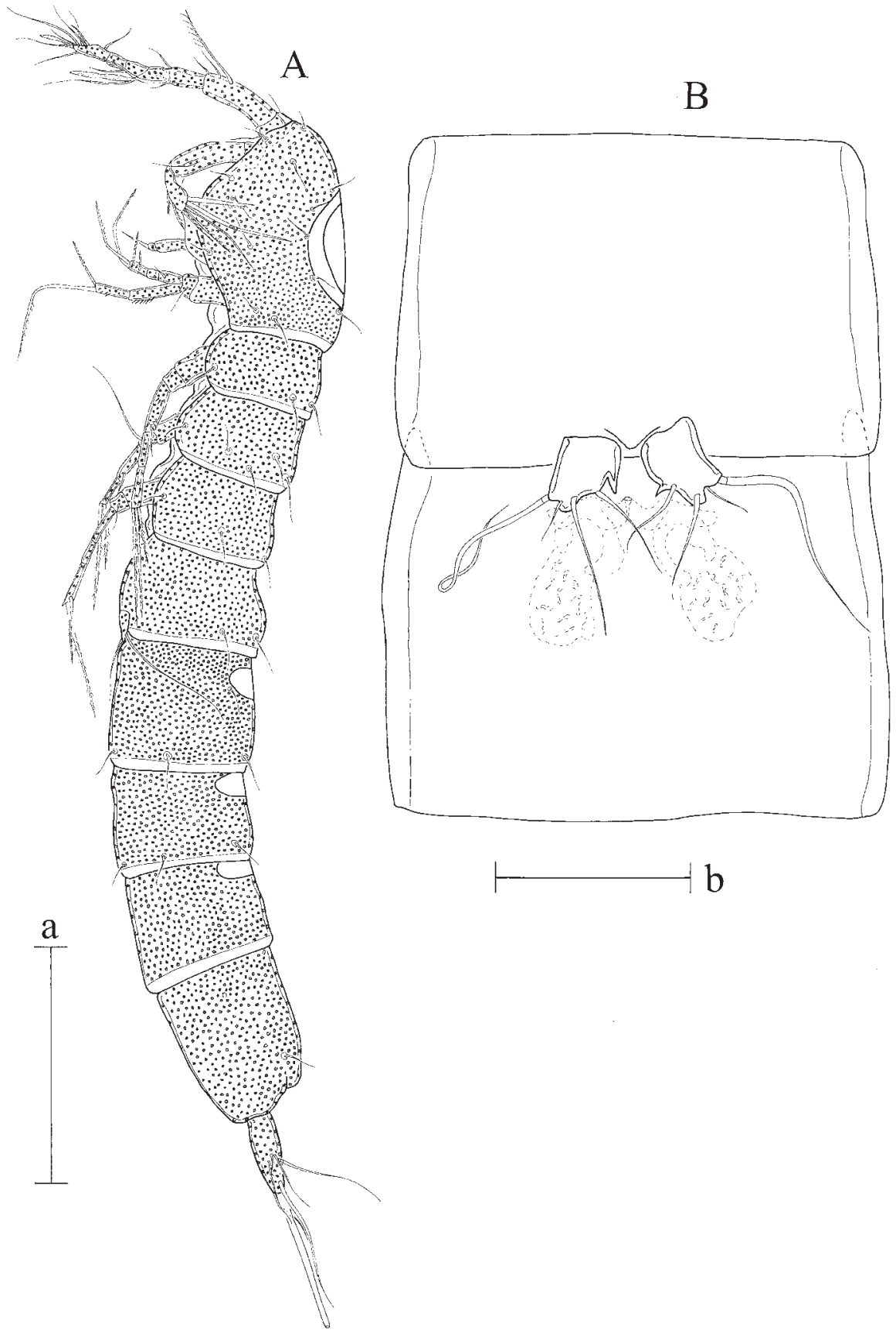

Fig. 5. Female lateral habitus (A), leg 5 and genital somite (B) of Remaneicaris ignotus (Dussart, 1983). Scale bar a, for habitus $-100 \mu \mathrm{m}$; scale bar b, for ventral view of the first urosomite with leg 5 and double genital somite $-20 \mu \mathrm{m}$.

Рис. 5. Самка Remaneicaris ignotus (Dussart, 1983): общий вид сбоку (А), 5-я нога и генитальный сегмент (B).

Масштабные отрезки: А - 100 мкм; В - 20 мкм. 


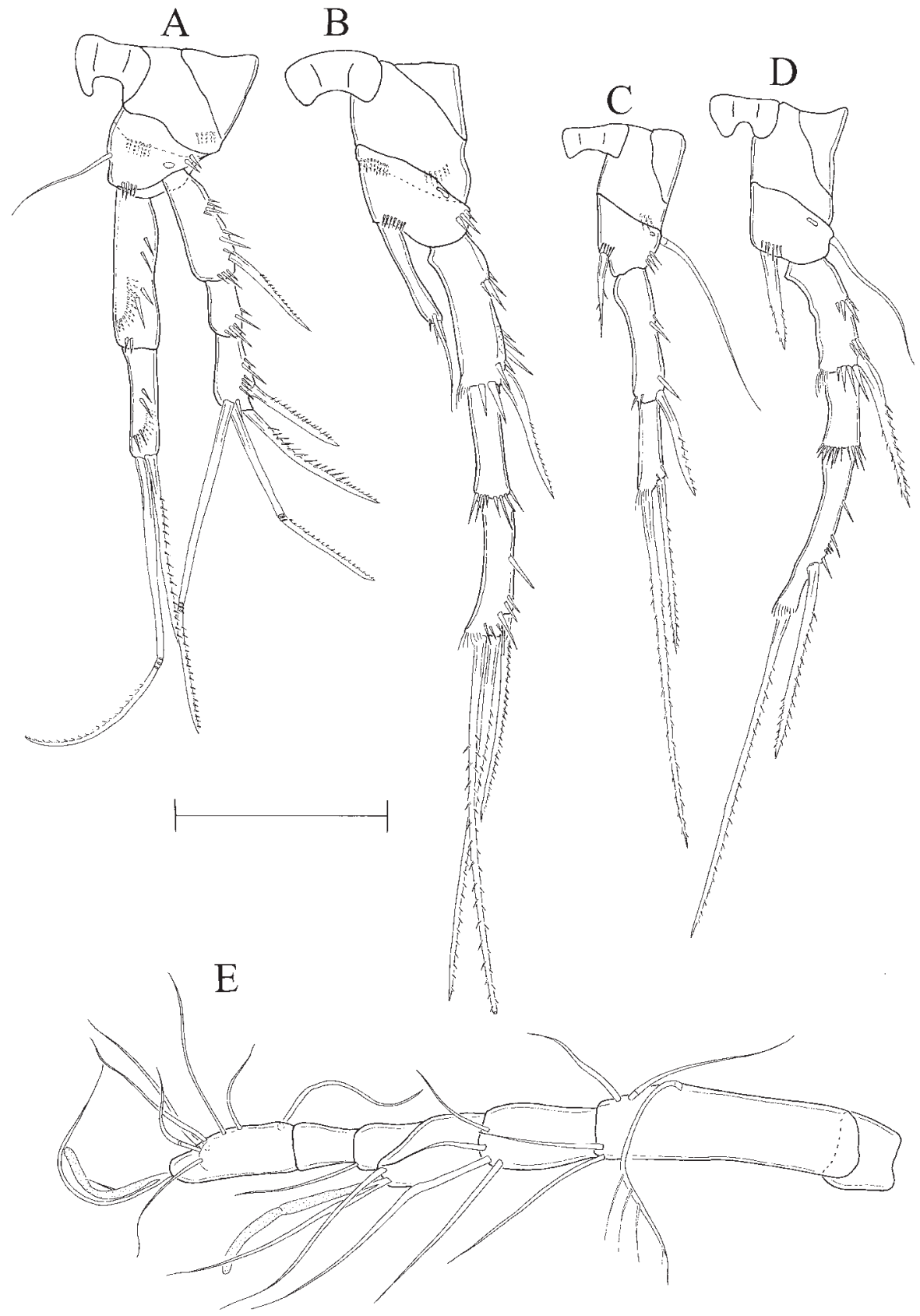

Fig. 6. Female leg 1 (A), leg 2 (B), leg 3 (C), leg 4 (D) and antennule (E) of Remaneicaris ignotus (Dussart, 1983).

Scale bar $20 \mu \mathrm{m}$.

Рис. 6. Самка Remaneicaris ignotus (Dussart, 1983): плавательная нога 1 (А), плавательная нога 2 (В), плавательная нога 3 (C), плавательная нога 4 (D), антеннула (Е).

Масштабный отрезок 20 мкм. 
occurs at the same level of the setae I, II and III, a character not found in Siolicaris sioli. In this species, as well as in some other related neotropical genera, the dorsal setae occurs, normally, in a more distal position, while the setae I, II and III have a more proximal arrangement.

Also, individuals of $R$. ignotus differ from Siolicaris as well as from the other Parastenocarididae by the subdistal position of the outer seta of the $3^{\text {rd }}$ exp of leg 4 (autR; for a discussion about convergent appearance of this character, see Corgosinho \& Martínez Arbizu, 2005), and by a set of other derived and plesiomorphic characters that were observed only in members of Remaneicaris. We can mention the presence of an endopod on the leg 3 of males (plesiomorphy), the presence of at least one big spinule medially placed on the outer margin of the third exopodite of the legs 2 and 4 (autR), leg 5 without intercoxal sclerite (autR) but with a less chitinized plate between these limbs, and not connecting them (autapomorphy for $R$. igno$t u s)$, first endite of $\mathrm{Mx} 2$ with two setae ( $\mathrm{pl}$ ) and the presence of three slender setae on the second endite of $\mathrm{Mx} 2(\mathrm{pl})$.

These characters associated with the Mx2 are particularly interesting to reconstruct the phylogeny of the family, since all other Parastenocarididae, including $S$. sioli, share, as a synapomorphy, the presence of only one seta on the first endite of $\mathrm{Mx} 2$, while in the second endite, one seta is transformed into a serrated spine. Another synapomorphy of the remaining Parastenocarididae is the absence of an enp on the leg 3 of males.

Although considered as a typical Remaneicaris, $R$. ignotus shows a set of unusual plesiomorphic characters within the genus and the lack of less inclusive synapomorphies with other groups of species withinRemaneicaris so that it should occupy the most basal position within the genus. Thus, in accordance with Corgosinho (2007) this species is the sister-taxon of a group including $R$. meyerabichi plus all other Remaneicaris species, viz. ( $R$. ignotus ( $R$. meyerabichi (Remaneicaris spp.))).

In accordance with Corgosinho \& Martínez Arbizu (2005), the presence of integumental windows seems to be a character present in the groundpattern of Parastenocarididae according to the following pattern: 1 dorsal window on the cephalothorax, 1 dorsal window on urosomites $2-5$, in males, and urosomites $2-4$, in females (due to the genital double somite). Within $R e$ maneicaris almost all species show dorsal integumental windows on the cephalothorax, second urosomite and a single lateral integumental window on the fifth urosomite although in some undescribed species this window appears divided into two lateral windows on each side of the body. Other patterns can also be seen within the genus. For example, $R$. analuizae Corgosinho \& Martínez Arbizu, 2005 shows, besides the common integumental lateral window of the fifth urosomite, a lateral window also on the previous urosomite and in R. pluto (Noodt, 1965), $R$. hecate (Noodt, 1965), R. persephone (Noodt, 1965 ) and $R$. oncophora (Noodt, 1965) the dorsal window of the second urosomite is divided into two smaller windows located on the laterodorsal margin of the somite. Within Remaneicaris, only $R$. ignotus, $R$. meyerabichi and $R$. palaciosi have a dorsal window in more than one urosomite, although one dorsal window on each urosomite can be seen only, within Remaneicaris, in $R$. ignotus. In $R$. meyerabichi and $R$. palaciosi, considering only the males, a dorsal integumetal window occur in the cephalotorax and urosomites 2 and 5 .

As already mentioned by Corgosinho \& Martínez Arbizu (2005), it seems that there are several steps involved in these transformations that could be of phylogenetic relevance. These authors mentioned the "elongation" of the dorsal urosomal windows to the lateral position, the splitting of the dorsal windows on urosomites 4 and 5 into lateral windows, the loss of the windows on the fourth urosomite, and the loss of the windows on the third urosomite. At this moment, however, new data based on a phylogenetic reconstruction of the genus (Corgosinho, 2007) brought new light to this scenario. Thus, it is more parsimonious to assume that the steps involved are: first, the loss of the dorsal integumental windows on urosomites 3 and 4, keeping dorsal in the $5^{\text {th }}$ urosomite. This condi- 


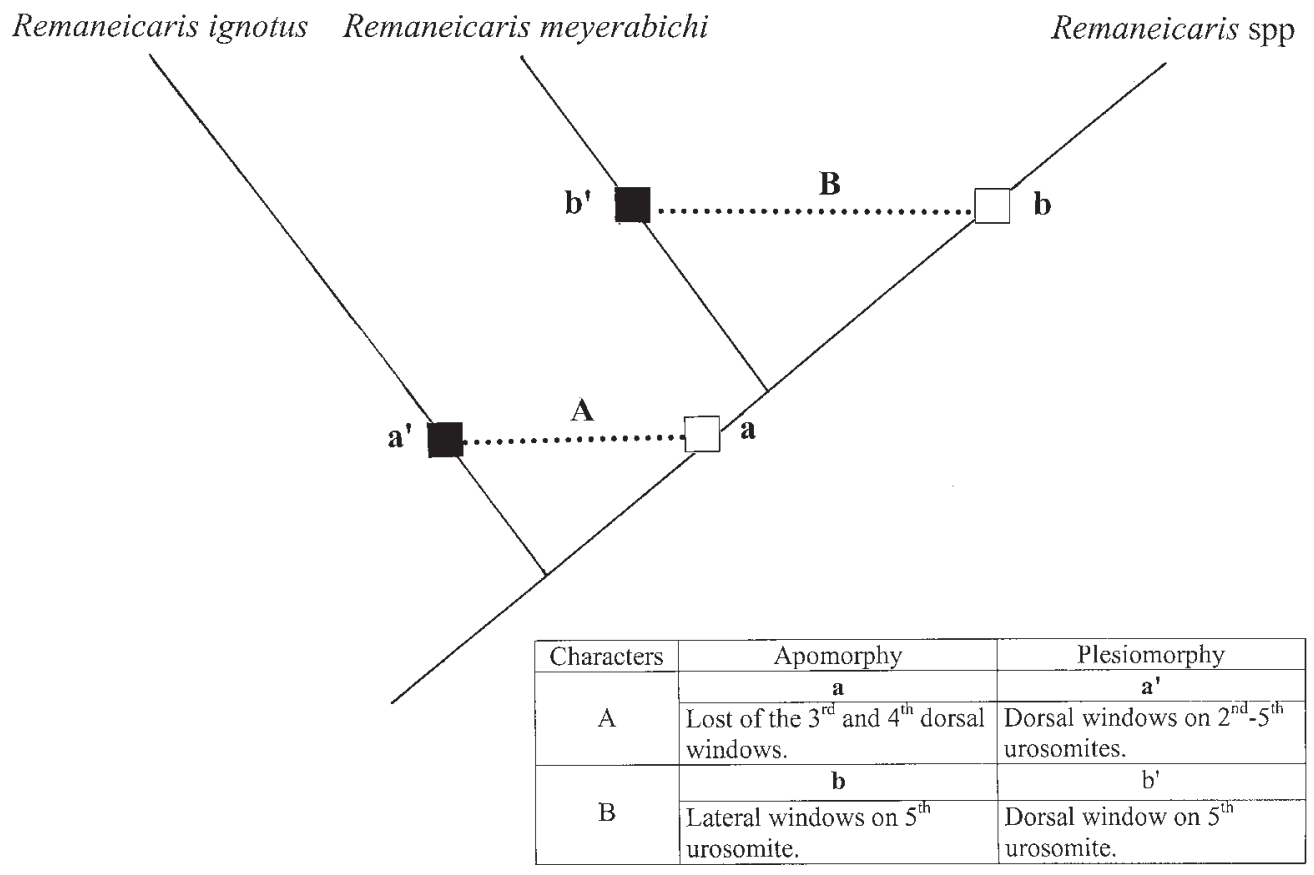

Fig. 7. Schema of the phylogenetic relationship at the basis of Remaneicaris, showing a hypothesis of how integumental windows patterns evolved within the genus.

Small table with the characters (A and B) and character states (a and a' - apomorphy and plesiomorphy, respectively, for character A; b and b' - apomorphy and plesiomorphy, respectively, for character B). Patterns based on males; in females, there is a fusion between the 2nd and 3rd urosomites, with the formation of a double genital somite.

Рис. 7. Схема филогенетических отношений в основании рода Remaneicaris, иллюстрирующая возможное направление эволюционного изменения положения интегументных окон (integumental windows).

В таблице приведены признаки (А и В) и состояния этих признаков (а и а' - апоморфные и плезиоморфные состояния признака $\mathrm{A}$, соответственно; $\mathrm{b}$ и $\mathrm{b}$ ' - апоморфные и плезиоморфные состояния признака $\mathrm{B}$, соответственно). Закономерности отражают положение интегументных окон у самцов, так как 2-й и 3-й сегменты уросомы самок сливаются и образуют двойной генитальный сегмент.

tion is present in $R$. meyerabichi and composes the groundpattern of the clade ( $R$. meyerabichi (Remaneicaris spp)). The second step involves the splitting of the dorsal integumental window of the $5^{\text {th }}$ urosomite into lateral windows, being it in the groundpattern of a clade formed by (Remaneicaris spp). The third and last step occurs in a more derived group within the clade (Remaneicaris spp) and is represented by the splitting of the dorsal integumental window of the $2^{\text {nd }}$ urosomite into two dorsolateral windows. Other observed patterns, such as the presence in $R$. analuizae of a lateral integumental window also on the $4^{\text {th }}$ urosomite of males, seems that has been evolved independently and a hypothetical ancestor with lateral windows in the fourth and fifth urosomites prior to the condition normally observed, with one lateral integumental window occurring only on the fifth urosomite, is not supported by the phylogeny (Fig. 7).

According to Martínez Arbizu \& Moura (1994), all the Parastenocarididae share, as a synapomorphy, the loss of the inner seta on the basis of leg 1 . However, the presence of this inner seta on both genders of $R$. ignotus is an indication that this character is present in the groundpattern of the family and thus, should be 
considered as a plesiomorphy, since it also occurs in the sister group. The presence of this structure in other Parastenocarididae is probably a homoplasy, but until now, it is impossible to know if it appeared several times or if it is present in the groudpattern of a more inclusive group outsideRemaneicaris, being subsequently lost several times also within the family. Other structures, within the Parastenocarididae, have been or can be misinterpreted with a true inner spine. For example, an observation of Murunducaris juneae Reid, 1994 as well as some as yet undescribed species of Murunducaris Reid, 1994 revealed that there is a dimorphic inner spinule on the basis of the leg 1 of the males, with one small spinule on each side. We interpret this element not necessarily as a dimorphic spine or seta, like those found in the Ameiridae, since, in the female, in the same position, there is a row of three small spinules (the middle spinule is a little bigger than the others) and no seta at this position. There is no homology between spinule and spine or seta. The presence of a protrusion on the inner margin of the basis of leg 1 in the males of some species of Parastenocaris was hypothesized by Bruno \& Cottarelli (1998) as being a possible homology with the true dimorphic spine observed on the inner margin of the basis of Ameiridae males. In accordance with Galassi \& De Laurentiis (2004), this protrusion observed in some Parastenocarididae seems to be similar to a transformation of the inner margin of the basis that can be seen in several Diosaccidae Sars, 1906 and Thalestridae Sars, 1905 and is not homologous with the inner basal setae, since in most cases within these families, males show an inner protrusion accompanied by an untransformed seta.

Another very distinctive character of Remaneicaris ignotus is the presence of a proximal linear row of spinules on the outer margin of the first exopodite of leg 2 and leg 4. This character is shared, as a plesiomorphy, with all other known Parastenocarididae outside Remaneicaris. Within Remaneicaris this character probably evolved in two steps, from linear until a pronounced "V" shaped distribution, passing through a moderate "v" condition.
The condition of leg 5 without intercoxal sclerite is an autapomorphy of Remaneicaris. The genus Simplicaris Galassi \& De Laurentiis, 2004 is characterized by the loss of leg 5 and has, therefore, no intercoxal sclerite. However, it is difficult to know if other parastenocaridids have also lost the intercoxal sclerite because this structure is seldom described. A sclerite connecting both limbs of leg 5 is present in both sexes of Parastenocaris hispanica Martínez Arbizu, 1997 for instance and can be seen also in Murunducaris as a hypertrophied plate.

The position of the leg 5 is another interesting feature of $R$. ignotus. In this species, these limbs are more ventrally located and not displaced to the ventro-lateral margins of the urosome, as can be seen in the other species within the genus. Thus, in view of the ventral position occupied by these limbs in other groups within the family and considering the basal position occupied by $R$. ignotus within the genus, we consider the presence of a more ventral leg 5 as a plesiomorphy within Remaneicaris.

\section{Acknowledgements}

We would like to thank Dr. Danielle Defaye for the loan of the type material of $R$. ignotus. We thank the staff of the Deutsches Zentrum für Marine Biodiversitätsforschung (Forschungsinstitut Senckenberg) for their help during the stay of the first author in Germany. This work is a part of the first author's PhD Thesis and was supported by the Deutscher Akademischer Austausch Dienst (DAAD), the Coordenação de Aperfeiçoamento de Pessoal de Nível Superior (CAPES, Brazil), the Fundação de Amparo a Pesquisa do Estado do Amazonas (FAPEAM, Brazil) and the Forschungsinstitut Senckenberg (Germany). We are also indebted with the anonymous referees who contributed to the final version of this manuscript.

\section{References}

Bruno M.C., Cottarelli V. 1998. Description of Parastenocaris amalasuntae n. sp. and new data on Parastenocaris proserpina and Parastenocaris pasquinii from 
subterranean waters of central Italy (Copepoda, Harpacticoida) // Italian Journal of Zoology. Vol.65. P.121136.

Corgosinho P.H.C. 2007. Phylogenetic systematic of Remaneicaris Jakobi (Copepoda, Harpacticoida, Parastenocarididae) from the neotropical region. Instituto Nacional de Pesquisas da Amazônia/ Universidade Federal do Estado do Amazonas, Manaus, PhD Thesis. 326 pp.

Corgosinho P.H.C., Martínez Arbizu P. 2005. Two new interstitial species of Remaneicaris Jakobi (Copepoda, Harpacticoida, Parastenocarididae) from the Ribeirão do Ouro river, Brazil, with a redefinition of the genus // Senckenbergiana biologica. Vol.85. No.2. P.147-162.

Corrales de Jacobo M.A., Frutos S.M. 1985. Estudio preliminar del zooplancton de la laguna Sirena (Corrientes, Argentina) // Physis. Vol.43. No.104. P.43-48.

Dussart B.H. 1983. Sobre algunos Copépodos de America del Sur. III // Comunicaciones Científicas del CECOAL (Centro de Ecología Aplicada del Litoral),
Argentina. Vol.16. P.1-8.

Galassi D.M.P., De Laurentiis P. 2004. Towards a revision of the genus Parastenocaris Kessler, 1913: establishment of Simplicaris gen. nov. from groundwaters in central Italy and review of the $P$. brevipes-group (Copepoda, Harpacticoida, Parastenocarididae) // Zoological Journal of the Linnean Society. Vol.140. P.417436.

Huys R., Boxshall G. 1991. Copepod Evolution. London: The Ray Society. 468 pp.

Martínez Arbizu P., Moura G. 1994. The phylogenetic position of the Cylindropsyllinae Sars (Copepoda, Harpacticoida) and the systematic status of the Leptopontiinae Lang. // Zoologische Beiträge. Vol.35. No.1. P. 55-77.

Noodt W. 1965. Crustacea subterranea aus Argentinien // Beiträge zur Neotropischen Fauna. Vol.4. P.84-129.

Schminke H.K. 1991. Sexual Dimorphism in Furcal Rami of Parastenocarididae (Copepoda: Harpacticoida) // Bulletin of the Plankton Society of Japan. Special Volume. P.573-584.

Responsible editors: V.N. Ivanenko \& F.D. Ferrari

Accepted April 20, 2007

Published online May 25, 2007 